\title{
EFEKTIVITAS NASI BERAS, MERAH (ORYZA NIVARA) TERHADAP KADAR KOLESTEROL TOTAL PENDERITA HIPERKOLESTEROLEMIA
}

\author{
Nonce Nova Legi ${ }^{1}$, Mirna Kawulusan', Yohanis Tomastola1, dan \\ Marsteivi Olivia Gedoan ${ }^{1}$ \\ Jurusan Gizi Poltekkes Kemenkes Manado \\ Email korespondensi : noncenovalegi@gmail.com
}

\begin{abstract}
Hypercholesterolemia is an increase in total cholesterol levels in the blood beyond the normal limits. Excess cholesterol levels in the blood will have an impact on degenerative diseases. Brown rice (oryza nivara) is a rice rich in vitamins, minerals and contain water soluble fiber that can help bind cholesterol, then throw it out of the body. Regular consumption of brown rice is very beneficial for health that can reduce levels of $L D L$. The aim of this research is to know the effectiveness of brown rice rice to total cholesterol level in hypercholesterolemia patient in Vilage Sea Pineleng District of Minahasa Regency. The type of this research is Quasi Eksperimen with One Group of Pretest and Posttest Design. The sample in this study is the entire population of hypercholesterolemia patients recorded in Posbindu Village Sea Pineleng District Minahasa regency that meets the inclusion criteria. Rice brown rice is given for 8 consecutive days every morning, day and night. Total cholesterol levels were measured before and after administration of brown rice. Data analysis using Paired t-test. The results showed that the total cholesterol level before the study was the highest of $\mathbf{3 6 0}$ $\mathrm{mg} / \mathrm{dl}$, the lowest was $216 \mathrm{mg} / \mathrm{dl}$, and after the highest total cholesterol was $298 \mathrm{mg}$ / $d l$, the lowest was $164 \mathrm{mg} / \mathrm{dl}$. The result of statistical test shows that $p=0,019(p<0,05)$, which means that there is difference of total cholesterol before and after giving of rice of red rice to hypercholesterolemia patient in Vilage Sea Pineleng Sub-district of Minahasa Regency.
\end{abstract}

Keywords: Brown Rice, Hypercholesterolemia, Total Cholesterol Level

\section{PENDAHULUAN}

Penyakit tidak menular (PTM) menjadi penyebab utama kematian secara global. Data World Health Organization (WHO), menunjukkan bahwa dari 57 juta kematian yang terjadi di dunia pada tahun 2008, sebanyak 36 juta atau hampir dua pertiganya disebabkan oleh Penyakit Tidak Menular. PTM juga membunuh penduduk dengan usia yang lebih muda. Di negara-negara dengan tingkat ekonomi rendah dan menengah, dari seluruh kematian yang terjadi pada orang-orang berusia kurang dari 60 tahun, 29\% disebabkan oleh PTM, sedangkan di negara-negara maju, menyebabkan $13 \%$ kematian. dan salah satu penyakit tidak menular adalah hiperkolesterolemia (Kemenkes RI, 2012).

Berdasarkan data yang diperoleh dari Riskesdas tahun 2013, bahwa di Indonesia proporsi penduduk $\geq 15$ tahun dengan kadar kolesterol total di atas nilai normal yang merujuk nilai yang di tentukan pada NCEP-ATP III adalah sebesar 35,9 $\%$. Penurunan $1 \%$ kolesterol darah dapat mengurangi $2,3 \%$ risiko penyakit jantung koroner. Selanjutnya berdasarkan data yang diperoleh dari posbindu desa Sea pada 
bulan Januari 2017 jumlah penderita hiperkolesterolemia adalah 25 orang, data tersebut hanya berdasarkan pada masyarakat yang berkunjung di posbindu.

Menurut Fairudz \& Nisa, 2015 salah satu upaya yang dapat dilakukan untuk mencegah kondisi hiperkolesterolemia adalah dengan mengkonsumsi bahan makanan alami yang dapat menurunkan kadar kolesterol, salah satunya adalah dengan mengkonsumsi serat pangan (dietary fiber). Beras merah memiliki sifat hipoglisemik dan memiliki kandungan serat pangan (dietary fiber) dan antioksidan yang relatif tinggi, serta daya cerna pati yang rendah (Nurhidajah dkk, 2015).

\section{BAHAN DAN CARA}

Metode yang digunakan dalam penelitian ini adalah Quasi Eksperimen One Group Desain pretest dan posttest untuk melihat efektivitas pemberian nasi beras merah terhadap kadar kolesterol total pada penderita hiperkolesterolemia di desa Sea Kecamatan Pineleng Kabupaten Minahasa. Sampel dalam penelitian ini adalah seluruh populasi penderita hiperkolesterolemia yang tercatat di posbindu Desa Sea Kecamatan Pineleng Kabupaten Minahasa. Penelitian ini menggunakan uji Paired $t$ test untuk melihat perbedaan kadar kolesterol total sebelum dan sesudah pemberian nasi beras merah.

\section{HASIL}

\section{Karakteristik Responden}

Tabel 1. Distribusi Karakteristik Responden

\begin{tabular}{lcc}
\hline \multirow{2}{*}{ Karakteristik } & \multicolumn{2}{c}{ Jumlah } \\
\cline { 2 - 3 } Jenis Kelamin & $\mathrm{n}$ & $\%$ \\
Perempuan & 20 & 83,3 \\
Laki-laki & 4 & 16,7 \\
\hline Golongan Umur (Tahun) & & \\
30-40 & 1 & 4,2 \\
$41-50$ & 7 & 29,2 \\
$51-60$ & 11 & 48,8 \\
61-70 & 5 & 20,8 \\
& & \\
\hline Pekerjaan & 8 & 33,3 \\
Ibu Rumah Tangga (IRT) & 11 & 45,8 \\
Swasta & 1 & 4,2 \\
Sopir & 2 & 8,3 \\
Petani & 2 & 41,7 \\
Pensiunan & 10 & 58,3 \\
\hline Normal (>18.5-25) & 14 &
\end{tabular}


Tabel di atas menunjukkan bahwa jenis kelamin responden yang paling banyak yaitu perempuan berjumlah 20 orang $(83.3 \%)$. Golongan umur responden paling lebih banyak usia 51 - 60 tahun sebanyak 11 orang (48.8\%). Adapun Pekerjaan responden sebagian besar swasta yaitu sebanyak 11 orang (45.8\%). Sedangkan status gizi responden sebagian besar mempunyai status gizi gemuk yaitu sebanyak 14 responden $(58.3 \%)$.

\section{Perbandingan Kadar Kolesterol Total Sebelum dan Sesudah Pemberian Nasi Beras Merah}

Tabel 2. Tabel Perbandingan Hasil Pemeriksaan Kadar Kolesterol Total

\begin{tabular}{ccccc}
\hline \multirow{2}{*}{ Kadar Kolesterol } & \multicolumn{2}{c}{ Sebelum } & \multicolumn{2}{c}{ Sesudah } \\
\cline { 2 - 5 } & $\mathrm{n}$ & $\%$ & $\mathrm{n}$ & $\%$ \\
\hline Tinggi $(\geq 200 \mathrm{mg} / \mathrm{dl})$ & 24 & 100 & 13 & 54.2 \\
Normal $(<200 \mathrm{mg} / \mathrm{dl})$ & 0 & 0 & 11 & 45.8 \\
\hline Jumlah & 24 & 100 & 24 & 100 \\
\hline
\end{tabular}

Berdasarkan hasil yang diperoleh dari tabel 2, diketahui, kadar kolesterol total sebelum pemberian nasi beras merah $\geq 200 \mathrm{mg} / \mathrm{dl}$ sebanyak 24 orang $(100 \%)$, sedangkan setelah diberikan nasi beras merah kadar kolesterol total $<200 \mathrm{mg} / \mathrm{dl}$ sebanyak 11 orang $(45.8 \%)$, dan kadar kolesterol $\geq 200 \mathrm{mg} / \mathrm{dl}$ sebanyak 13 orang $(54.2 \%)$.

\section{Analisis Bivariat}

Tabel 3. Hasil Analisis Statistik Uji Paired t-test kadar kolesterol total sebelum dan sesudah pemberian nasi beras merah.

\begin{tabular}{cccccccc}
\hline $\begin{array}{c}\text { Kadar Kolesterol } \\
\text { Total }\end{array}$ & $\mathrm{n}$ & Mean & Median & SD & Minimun & Maximum & $\mathrm{p}^{\text {Value }}$ \\
\hline Sebelum $(\mathrm{mg} / \mathrm{dl})$ & 24 & 271.75 & 273.5 & 36.325 & 216 & 360 & 0 \\
Sesudah $(\mathrm{mg} / \mathrm{dl})$ & 24 & 212.38 & 204 & 36.185 & 164 & 298 & 0,019 \\
\hline
\end{tabular}

Berdasarkan data yang diperoleh dari tabel 3. Diketahui rata-rata kadar kolesterol total saat pre test yaitu $273.75 \mathrm{mg} / \mathrm{dl}$, dengan kadar kolesterol total terendah yaitu $216 \mathrm{mg} / \mathrm{dl}$ dan, kadar kolesterol total tertinggi yaitu $360 \mathrm{mg} / \mathrm{dl}$, dan pada saat post test rata-rata kadar kolesterol total yaitu $204 \mathrm{mg} / \mathrm{dl}$ dengan kadar kolesterol total terendah yaitu $164 \mathrm{mg} / \mathrm{dl}$, dan kadar kolesterol total tertinggi yaitu $298 \mathrm{mg} / \mathrm{dl}$. Hasil uji statistik Paired t-test terdapat perbedaan kadar kolesterol total sebelum dan sesudah pemberian nasi beras merah pada penderita hiperkolesterolemia di desa sea kecamatan pineleng kabupaten minahasa, dengan hasil $p=0,019$.

\section{PEMBAHASAN}

1. Karakteristik Responden

Hasil penelitian menunjukan bahwa jenis kelamin responden paling banyak adalah perempuan. Menurut Ruslianti 2014, bahwa jenis kelamin dapat mempengaruhi terjadinya peningkatan kadar kolesterol dalam darah, khususnya pada 


\section{GIZIDO Volume 11 No.1 Mei 2019 Efektivitas Nasi Nonce Nova Legi dkk}

perempuaan yang setelah menopause kadar kolesterolnya cenderung akan meningkat, karena seorang perempuan yang belum menopause memiliki kadar kolesterol yang lebih rendah dibandingkan dengan kadar kolesterol laki-laki dengan usia yang sama. Hasil Penelitian menunjukan bahwa umur responden lebih banyak yaitu $51-60$ tahun berjumlah 11 orang $(48.8 \%)$ dan lebih sedikit yaitu berkisar pada umur $30-40$ tahun berjumlah 1 orang $(4,2 \%)$. kadar kolesterol meningkat tinggi seiring dengan bertambahnya usia pada manusia baik perenpuan maupun laki-laki. Pada laki-laki kadar kolesterol terlihat meningkat pada usia berkisaran 45 - 54 tahun, sedangkan untuk wanita pada usia antar 55-64 tahun (Hasdianah \& Suprapto, 2014).

Hasil penelitian menunjukan bahwa pekerjaan responden yaitu IRT sebanyak 8 orang $(33.3 \%)$, responden dengan pekerjaan swasta yaitu berjumlah 11 orang (45.8\%), dan untuk pekerjaan sopir yaitu 1 orang (4.2\%), sedangkan untuk responden dengan pekerjaan petani dan pensiunan yaitu masing-masing berjumlah 2 orang $(8,3 \%)$. Menurut Sandi dkk 2008, bahwa pekerja kantoran lebih dominan memiliki kadar kolesterol yang tinggi, dibandingkan dengan pekerja kasar. Status gizi responden Normal sebanyak 10 orang $(41.7 \%)$, status gizi Gemuk sebanyak 14 orang $(58.3 \%)$.

Menurut Anies (2015), bahwa kegemukan cenderung berdampak terhadap meningkatnya kadar kolesterol total VLDL, dan LDL. Tidak semua orang yang memiliki status gizi lebih kadar kolesterolnya meningkat melebihi batas normal. Faktor herediter pula memiliki peranan yang penting dalam menentukan kadar kolesterol pada seseorang atau riwayat keluarga yang memiliki kolesterol tinggi, pola makan, aktifitas fisik bahwa riwayat merokok (Wongkar dkk, 2013). hiperkolesterolemia atau kadar kolesterol yang berlebih kebanyakan diderita oleh orang yang memiliki status gizi obesitas dan orang yang sudah lanjut usia tetapi tidak menutup kemungkinan hiperkolesterolemia juga dapat menyerang orang dengan status gizi normal bahkan di usia muda (Rini dkk 2014, dalam Fitnella, 2009).

\section{Asupan Energi Sebelum dan Sesudah Pemberian Nasi Beras Merah}

Asupan energi merupakan konsumsi yang berasal dari makanan yang dibutuhkan tubuh dalam melakukan aktifitas. Dari hasil recall 1×24 jam diketahui asupan energi responden terendah sebelum mengkonsumsi nasi beras merah yaitu $1104.5 \mathrm{kkal}(51.37 \%)$, dan tingkat asupan tertinggi yaitu $1548.6 \mathrm{kkaal}(99.91 \%)$, untuk tingkat asupan energi responden pada saat pemberian nasi beras merah tertinggi yaitu $1421.3 \mathrm{kkal}(91.7 \%)$, dan energi terendah yaitu $1091.2 \mathrm{kkal}(57.43 \%)$.

Asupan energi berasal dari makanan yang dikonsumsi yang terdiri dari sumber karbohidrat, protein,lemak yang berfungsi sebagai menunjang pertumbuhan, mempertahankan hidup serta melakukan aktifitas fisik. Kesimbangan asupan energi dipengaruhi oleh asupan yang masuk dengan energi yang keluar, kelebihan asupan energi terjadi bila asupan energi melebihi energi yang keluar karena kelebihan asupan dalam tubuh diubah menjadi lemak sehingga dapat mengakibatkan kelebihan berat badan, sedangkan kekurangan asupan energy terjadi ketika kurangnya asupan energi yang dikonsumsi dan energy yang keluar melebihi asupan, konsisi tersebut dapat menyebabkan penurunan berat badan (Almatsier, 2010).Asupan energi dapat dipengaruhi oleh beberapa faktor yaitu usia, berat badan, tinggi badan, pola makan dan juga status sosial (Kartasapoetra dan Marsetyo, 2010). 


\section{GIZIDO Volume 11 No.1 Mei 2019 Efektivitas Nasi Nonce Nova Legi dkk}

\section{Asupan Serat Sebelum dan Sesudah Pemberian Nasi Beras Merah}

Dari hasil penelitan diketahui tingkat asupan serat responden terendah pada saat sebelum pemberian nasi beras merah yaitu $2.6 \mathrm{gr}(8.66 \%)$, dan tingkat asupan tertinggi yaitu $8.6 \mathrm{gr}(28.67 \%)$, sedangkan asupan serat tertinggi responden pada saat pemberian nasi beras merah yaitu $18.5 \mathrm{gr}(84.09 \%)$, dan terendah yaitu $13.9 \mathrm{gr}$ (46.33 $\%)$.

konsumsi serat pangan (dietary fiber), dapat menurunkan konsentrasi kolesterol dalam darah. Serat pangan dapat menghambat absorpsi kolesterol yang berada diusus halus sehingga menurunya konsentrasi kolesterol dalam plasma dan meningkatnya sintesis kolesterol oleh hati, sintesis empedu, dan ekskresi kolesterol melalui feses. Oleh karena itu, serat pangan telah banyak digunakan dan direkomendasikan untuk menjaga konsentrasi kolesterol darah supaya tetap normal (Hernawati dkk, 2013).

Dalam saluran pencernaan, serat larut mengikat asam empedu (produk akhir kolesterol) sehingga asam empedu tidak lagi diserap ke dalam usus halus melainkan dikeluarkan bersama kotoran. Untuk menggantikan hilangnya asam empedu, hati akan menarik kolesterol dari darah yang dapat menyebabkan total kadar kolesterol darah akan menurun. Dengan demikian, makin tinggi konsumsi serat larut, akan semakin banyak asam empedu dan lemak yang dikeluarkan oleh tubuh (Wolk dkk, 2017)

Serat larut air bermanfaat dalam menurunkan kadar LDL dan kadar glukosa darah, (Anies,2015). Menurut Jusup L, 2010, kandungan serat pada beras merah sangat baik untuk penderita jantung dan diabetes, karena dapat membantu mengendalikan kadar gula darah dan kolesterol darah. Dalam beras merah terkandung zat anti kanker yang terdiri dari serat, selenium dan senyawa fitokimia yaitu fenolat dan lignin. Mengkonsumsi minimal 6 porsi beras merah selama satu minggu sangat baik untuk wanita pasca menopause yang mempunyai masalah dengan peningkatan kadar kolesterol, tekanan darah tinggi dan gejala penyakit jantung (Purwasasmita M, 2010).

Menurut Almatsier 2004, bahwa seseorang yang memilki kadar kolesterol dalam darah tinggi, salah satu syarat dietnya yaitu dengan mengkonsumsi serta tinggi, terutama serat larut air termasuk apel, beras merah, havermout dan kacangkacangan. Konsumsi beras merah secara rutin sangat bermanfaat bagi kesehatan yaitu dapat menurunkan kadar LDL, mencegah penyakit jantung koroner, mencegah kanker, serta dapat menurunkan resiko diabetes mellitus (Subroto,2008).

\section{Kadar Kolesterol Total Sebelum dan Sesudah Pemberian Nasi Beras Merah}

Penelitian ini menggunakan jenis peneliitian Quasi Eksperimen dengan menggunakan rancangan One Group Desain pretest dan posttest. Penelitian ini melihat perbedaan kadar kolesterol total sebelum dan sesudah pemberian nasi beras merah pada penderita hiperkolesterolemia. Sebelum diberikan nasi beras merah diukur kadar kolesterol total dari 24 orang responden yang menjadi sampel yang memiliki kadar kolesterol total $\geq 200 \mathrm{mg} / \mathrm{dl}$. Nasi beras merah adalah, nasi yang berasal dari beras merah yang diberikan kepada penderita sebagai pengganti nasi 
putih dan diberikan 3 kali sehari selama 8 hari berturut-turut yaitu pada pagi hari diberikan $100 \mathrm{gr}$ nasi beras merah, sedangkan pada siang dan malam hari diberikan 200 gr. Pada hari kesembilan dilakukan kembali pemeriksaan kadar kolesterol total dari penderita hiperkolesterolemia. Hasil pemeriksaan kadar kolesterol total dari 24 responden rerdapat 11 responden yang kadar kolesterol totalnya mengalami perubahan dari kategori tinggi ( $\geq 200 \mathrm{mg} / \mathrm{dl}$ ), menjadi kategori normal $(<200 \mathrm{mg} / \mathrm{dl}$ ), sedangkan 13 responden lainnya masih dalam kategori tinggi namun kadar kolesterol totalnya mengalami perubahan.

Penelitian ini sejalan dengan penelitian yang dilakukan oleh Herlambang dkk 2015, tentang perbandingan efektivitas pemberian ekstrak beras hitam dan ekstrak beras merah terhadap perubahan Profil lipid tikus wistar (rattus novergicus), dengan tujuan untuk mengetahui efektivitas ekstrak beras merah dan beras hitam terhadap perubahan profil lipid, menyimpulkan bahwa Efektivitas pengaruh pemberian ekstrak beras hitam tidak berbeda dengan pengaruh pemberian ekstrak beras merah dalam menurunkan kadar total kolesterol dan trigliserida.

Demikian juga dengan penelitian yang dilakukan oleh Pradini dkk 2017, dengan menggunakan metode quasi experimental, dengan desain penelitian non randomized control-group pretest-postest design, Menyimpulkan bahwa pemberian nasi beras merah dapat menurunkan kadar kolestrerol total pada penderita DM tipe 2 dengan kadar kolestrol awal 235,69 mg/dL dan akhir 198,56 mg/dL. Begitu juga dengan hasil penelitian oleh Zang dkk 2011, terhadap 202 responden hasil penelitian menunjukan bahwa terjadi penurunan kadar kolesterol LDL pada kelompak intervensi yang diberikan beras merah dengan nilai $p=0.02(p=<0.05)$, dan terjadi peningkatan kolesterol HDL pada kelompok intervensi beras merah.

\section{KESIMPULAN}

Kadar kolesterol total sebelum perlakuan kadar kolesterol total terendah yaitu $216 \mathrm{mg} / \mathrm{dl}$ dan kadar kolesterol total tertinggi yaitu $360 \mathrm{mg} / \mathrm{dl}$. Sedangkan kadar kolesterol total sesudah perlakuan, yaitu $<200 \mathrm{mg} / \mathrm{dl}$ sebanyak 11 orang dan kadar kolesterol total $\geq 200 \mathrm{mg} / \mathrm{dl}$ yaitu sebanyak 13 orang, dimana rata-rata kadar kolesterol total yaitu $204 \mathrm{mg} / \mathrm{dl}$. Dapat disimpulkan bahwa terdapat perbedaan kadar kolesterol total sebelum dan sesudah pemberian nasi beras merah (Oryza Nivara).

Disarankan bagi responden agar dapat mengatur pola makan dan mengurangi makanan yang banyak mengadung sumber lemak yang dapat memicu terjadinya peningkatan kadar kolesterol total.

\section{DAFTAR PUSTAKA}

Almatsier S. 2004. Penuntun Diet Edisi Baru. Gramedia Pustaka Utama. Jakarta. Almatsier S. 2010. Penuntun Diet Edisi Baru. Gramedia Pustaka Utama. Jakarta Anies. 2015. Kolesterol dan Penyakit Jantung Koroner. AR-RUUZ MEDIA. Yogjakarta.

Arifiyanti DW. 2016. Hubungan Asupan Energi Dan Lemak Dengan Status Gizi Pada Remaja Putri Di Pondok Pesantren Ta'mirul Islam Surakarta.

Fairudz A, Nisa K. 2015. Pengaruh Serat Pangan Terhadap Kadar Kolesterol Penderita Overweight 
Herlambang AH, Kapantow HN, Kawengian SES. 2015. Perbandingan Efektivitas Pemberian Ekstrak Beras Hitam Dan Ekstrak Beras Merah Terhadap Perubahan Profil Lipid Tikus Wistar (rattus novergicus). J. Ilmu dan Teknologi Pangan, Vol. 3 No. 1 Th. 2015. Diakses Melalui

Hasdianah HR, Suprapto IS. 2014. Patologi dan Patofisiologi Penyakit. Nuha Medika. Yogjakarta.

Hernawati, Manalu W, Suprayogi A, Astuti AD. 2013. Perbaikan Parameter Lipid Darah Mencit Hiperkolesterolemia dengan Suplemen Pangan Bekatul.

Jusup L. 2010. Makanan Untuk Meningkatkan Daya Tahan Tubuh. PT Gramedia Pustaka Utama. Jakarta

Kartasapoetra, G dan Marsetyo, 2010. IImu Gizi: Korelasi Gizi, Kesehatan dan Produktivitas kerja. Jakarta: Rineka Cipta

Kemenkes, 2013. Laporan Riset kesehatan dasar tahun 2013. Badan Litbangkes Kemenkes.R.I.2013

Kemenkes RI, 2012. Penyakit Tidak Menular. Buletin Jendela Data \& Informasi Kesehatan.

Nurhidajah, Astuti M,Sardjono, Murdiati A, Marsono Y. 2015. Kadar Serat Pangan Dan Daya Cerna Pati Nasi Merah Yang Diperkaya Kappa-Karagenan Dan Ekstrak Antosianin Dengan Variasi Metode Pengolahan. The $2^{\text {nd }}$ University Research Coloquium 2015.

Purwasasmita M. 2010. Padi Sry Organik Indonesia. Penebar Swadaya Group

Pradini UW, Marchianti NCA, Rianti R. 2017. Efektivitas Nasi Merah Untuk Menurunkan Kadar Kolesterol Total Pasien DM Tipe 2.

Ruslianti. 2014. Kolesterol Tinggi Bukan Untuk Ditakuti. FMedia. Jakarta Selatan

Rini PT, Karim D, Novayelinda R. 2014. Gambaran Kadar Kolesterol Pasien Yang Mendapatkan Terapi Bekam. JOM PSIK VOL. 1 NO. 2 Oktober 2014.

Sandi C, Saryono, Ramawati D. 2008. Perbedaan kadar kolesterol darah pada pekerja kantoran Dan pekerja kasar di desa majasari, bukateja Kabupaten purbalingga. Jurnal Keperawatan Soedirman (The Soedirman Journal of Nursing), Volume 3 No.3 Nopember 2008.

Subroto AM. 2008. Real Food True Health. PT Agromedia Pustaka. Jakarta.

Wongkar CM, Kepel JB, Hamel SR. 2013. Hubungan status gizi dengan kadar kolesterol total Pada masyarakat di kelurahan bahu kecamatan Malalayang manado. ejournal keperawatan e-Kep).

Wolk A, Manson EJ, Stampfer JM, Colditz AG, Hu BF, Speizer EF, Hennekens HC, Willet CW. 2017. Long - term Intake of Dietary Fiber and Decreased Risk of Coronary Heart Disease Among Women. 